\title{
Properties of particleboard made from pretreated particles of rubberwood, EFB and rubberwood-EFB blend
}

\begin{abstract}
The increasing use of low formaldehyde emission adhesives such as Melamine Urea Formaldehyde (MUF) for bonding particleboard and other wood composites has led researchers to find ways to improve the durability of these products against biodeterioration agents. A study on the treatment of particleboard through soaking of particles with $2 \%$ boric acid and $0.2 \%$ deltamethrin solutions was conducted. Particleboards were produced utilizing treated particles of rubberwood (clone RRIM 2002), Empty Fruit Bunches (EFB) and rubberwood-EFB blend (70:30). A low formaldehyde emission MUF resin (E1-grade) was used as a binder. The boards were evaluated for resistance against termite and fungal attack, static bending, internal bonding and dimensional stability. The properties were compared with those of untreated boards. The results of this study showed that the resistance of E1 grade MUF-bonded rubberwood and EFB particleboards against white rot fungus (Pycnoporous sanguiness) and termite (Coptotermes curvignathus) can be enhanced through the proposed treatment method. The particleboards made from both rubberwood and rubberwood-EFB blend require longer pressing time (> $6 \mathrm{~min}$ ). Boric acid offered better protection against white rot wheras deltamethrin was more effective against termite. The bonding quality of both treated rubberwood and rubberwood-EFB blend boards was inferior compared to that of untreated board. Nonetheless, all treated EFB particleboards have higher IB. The strength and stiffness properties of rubberwood and rubberwood-EFB blend particleboards for both dry and wet conditions were markedly reduced by the treatments. The treatments increased the dry MOR and MOE values of EFB boards but lowered the wet MOR and MOE values. The study also indicated that the presence of preservatives had markedly decreased the stability of rubberwood and rubberwood-EFB blend particleboards.
\end{abstract}

Keyword: Particleboard, melamine urea formaldehyde, deltamethrin, boric acid, Pycnoporous sanguiness, Coptotermes curvignathus 